J. Clin. Chem. Clin. Biochem.

Vol. 19, 1981, pp. 387-394

\title{
A Simultaneous Radioimmunoassay for Aldosterone and Its Precursors: Human Plasma Levels Following the Inhibition of Converting Enzyme, Before and After Blockade of Prostaglandin Biosynthesis
}

\author{
By $H$. Witzgall ${ }^{1}$ ) and $S$. Hassan-Ali \\ with the technical assistance of $B$. Krischer \\ Medizinische Klinik Innenstadt (Director: Prof. Dr. E. Buchborn) der Universität München
}

(Received March 15, 1980/February 9,1981)

Summary: Plasma aldosterone, 18-hydroxycorticosterone, corticosterone, 18-hydroxydeoxycorticosterone, and deoxycorticosterone were determined in 15 healthy male volunteers ( $34 \pm 2$ years) following the inhibition of converting enzyme with captopril (SQ 14.225), either with or without indometacin pretreatment. These studies were performed with the aid of a radioimmunological method for the simultaneous determination of the steroids from $1.0 \mathrm{ml}$ of plasma. The procedure involves one extraction and one chromatographic step. Highly sensitive and specific rabbit antisera were raised for all steroids. Precision and accuracy are shown to be equivalent to those of single steroid radioimmunoassays. Without indometacin pretreatment a constant and significant fall in aldosterone and 18-hydroxycorticosterone plasma levels was obtained after captopril. 18-Hydroxydeoxycorticosterone and corticosterone did not change after inhibition of converting enzyme. Under indometacin pretreatment all basal steroid levels were significantly reduced. After captopril, aldosterone did not change and 18-hydroxycorticosterone showed a smaller decrease than without indometacin. 18-Hydroxydeoxycorticosterone and corticosterone increased significantly $1 \frac{112}{2}$ hour after captopril. We conclude that indometacin significantly reduces basal mineralocorticoid production of adrenal zona glomerulosa and fasciculata. Furthermore, the effect of captopril on aldosterone and 18-hydroxycorticosterone is abolished or diminished by inhibition of prostaglandin biosynthesis, but indometacin does not prevent an augmented secretion of 18-hydroxydeoxycorticosterone and corticosterone.

\section{Simultaner Radioimmunassay für Aldosteron und seine Vorstufen: Konzentrationen im Plasma des Menschen nach Hemmung des Converting Enzyme vor und nach Blockade der Prostaglandinbiosynthese}

Zusammenfassung: Aldosteron, 18-Hydroxycorticosteron, Corticosteron, 18-Hydroxydesoxycorticosteron und Desoxycorticosteron wurden im Plasma von 15 gesunden männlichen Probanden ( $34 \pm 2$ Jahre) nach oraler Gabe des Converting Enzyme-Inhibitors Captopril (SQ 14.225) bestimmt. Die Untersuchungen sind vor und nach einer Vorbehandlung mit Indömetacin durchgeführt worden. Es wird ein Radioimmunoassay beschrieben, mit dem die genannten Steroide simultan aus $1 \mathrm{ml}$ Plasma bestimmt werden können. Gegen alle Steroide konnten hoch sensitive und spezifische Antiseren erzeugt werden. Die Präzision und Richtigkeit der Methode ișt vergleichbar mit Radioimmunoassays, in denên nur ein Steroid bestimmt wird. Ohne Vorbehandlung mit Indometacin wurde nach Gabe von Captopril ein konstanter und signifikanter Abfall des Aldosteron und des 18-Hydroxycorticosteron im Plasma beobachtet. 18Hydroxydesoxycorticosteron und Corticosteron änderten sich nicht nach Captopril. Nach Vorbehandlung mit Indometacin waren alle basalen Steroidkonzentrationen signifikant erniedrigt. Auf Gabe von Captopril hin änderte sich die Aldosteronkonzentration nicht und 18-Hydroxycorticosteron fiel geringer ab als ohne Vorbehandlung mit Indometacin. 18-Hydroxydesoxycorticosteron und Corticosteron stiegen unter Indometacin 11/2 Stunden nach Captopril signifikañ an. Die Ergebnisse zeigen, daß Indometacin die basale Mineralocorticoidsekretion der Zona glomerulosa und fasciculata supprimiert. Weiterhin wird der Effekt von Captopril auf die Aldosteron- und 18-Hydroxycorticosteronkonzentration durch die vorherige Gabe von Indometacin aufgehoben bzw. reduziert. Die Vorbehandlung mit Indometacin kann jedoch eine gesteigerte Freisetzung von 18-Hydroxydesoxycorticosteron und Corticosteron nicht verhindern.

\footnotetext{
1) Supported by Deutsche Forschungsgemeinsohaft Wi 548/1,2.
} 


\section{Introduction}

The role of prostaglandins in the regulation of aldosterone ${ }^{2}$ ) secretion is not clearly defined. It is known that corticotropin stimulates the adrenocortical prostaglandin system which, on the other hand, has been proposed to mediate corticotropin induced steroidogenesis (1-3). Furthermore, studies with intact animals have suggested that the prostaglandin system modulates the angiotensin II stimulated aldosterone production (4). However, recent attempts failed to enhance directly the aldosterone secretion by different prostaglandin metabolites in vitro $(5,6)$. The effect of the inhibition of the prostaglandin system on the main precursur steroids of aldosterone has not yet been evaluated in man. Plasma levels of these steroids both with and without inhibition of prostaglandin biosynthesis may provide further knowledge about regulation of aldosterone.

We developed a radioimmunoassay for simultaneous measurement of aldosterone, 18-hydroxycorticosterone, corticosterone, and deoxycorticosterone. Studies were performed in healthy men under basal conditions and after inhibition of converting enzyme with captopril (SQ 14.225; 2-O-methyl-3-mercaptopropanoyl- $L$ proline), with and without the blockade of the prostaglandin system. It could be shown that all basal steroid levels were significantly suppressed by indometacin pretreatment. Furthermore, inhibition of prostaglandin biosynthesis by indometacin pretreatment altered the response of the steroids to converting enzyme inhibition.

\section{Materials and Methods}

Radioactive chemicals

$\left[1,2-{ }^{3} \mathrm{H}\right] 18$-hydroxy-11-deoxy corticosterone (specific radioactivity: $1.8 \mathrm{TBq} / \mathrm{mmol}, 51 \mathrm{Ci} / \mathrm{mmol} ; 1000$ counts $/ \mathrm{min}=2.8 \mathrm{pg}$ ), $\left[1,2(n)-{ }^{3} \mathrm{H}\right] 18$-hydroxycorticosterone $(1.1 \mathrm{TBq} / \mathrm{mmol}, 32 \mathrm{Ci} /$ $\mathrm{mmol}, 1000$ counts $/ \mathrm{min}=7.4 \mathrm{pg}),\left[1,2(\mathrm{n})^{3} \mathrm{H}\right] 11$-deoxycortico-

\footnotetext{
2) The following trivial names are used:

Aldosterone: 18,11 hemiacetal of $11 \beta, 21$-dihydroxy-3,20dioxo-4-pregnen-18-al.

Corticosterone: 11 $\beta, 21$-dihydroxy-4-pregnene-3,20-dione.

Cortisone: 17,21-dihydroxy-4-pregnene-3,11,20-trione.

Cortisol: $11 \beta, 17,21$-trihydroxy-4-pregnene-3,20-dione.

11-Deoxycortisol: 17,21-dihydroxy-4-pregnene-3,20-dione.

Deoxycorticosterone: 21 -hydroxy-4-pregnene-3,20-dione.

Oestradiol: 1,3,5(10)-oestratriene-3,17 $\beta$-diol.

18-Hydroxycorticosterone: $11 \beta, 18,21$-trihydroxy-4-pregnene3,20-dione.

18-Hydroxydeoxycorticosterone: 18,21-dihydroxy-4-pregnene3,20-dione.

Progesterone: 4-pregnene-3,20-dione.

Pregnenolone: $3 \beta$-hydroxy-5-pregnene-20-one.

Tetrahydroaldosterone: $3,11 \beta, 21$-trihydroxy-20-oxo-5 $\beta$-pregnan 18-ol.

Tetrahydrocorticosterone: $3,11 \beta, 21$-trihydroxy-20-oxo-5 $\beta$ pregnane.

Tetrahydrodeoxycorticosterone: 3,21 -dihydroxy-20-oxo-5 $\beta$ pregnane.

Testosterone: 17 $\beta$-hydroxy-4-androsten-3-one.
}

sterone (1.2 TBg/mmol, $35 \mathrm{Ci} / \mathrm{mmol} ; 1000$ counts $/ \mathrm{min}=5.0 \mathrm{pg})$ and $\left[1,2,6,7(\mathrm{n})^{-3} \mathrm{H}\right]$ aldosterone $(3.7 \mathrm{TBq} / \mathrm{mmol}, 102 \mathrm{Ci} / \mathrm{mmol}$; 1000 counts $/ \mathrm{min}=2.2 \mathrm{pg}$ ) were purchased from Amersham Buchler, Braunschweig. $\left[1,2,6,7(\mathrm{n})-{ }^{3} \mathrm{H}\right]$ corticosterone $(3.0 \mathrm{TBq} /$ $\mathrm{mmol}, 82.1 \mathrm{Ci} / \mathrm{mmol} ; 1000$ counts $/ \mathrm{min}=3.5 \mathrm{pg}$ ) was obtained from NEN, Langen (FRG). All radioactive chemicals were purified by thin layer chromatography before analysis.

\section{Pharmaceuticals}

Captopril (INN) (SQ 14.225; 2-O-methyl-3-mercaptopropanoyl$L$-proline) was kindly supplied as an investigational drug by Dr. R. K. Liedke (E. R. Squibb, von Heyden GmbH, Regensburg, FRG). Indometacin (INN): Amuno ${ }^{\circledR}$, Sharp \& Dohme GmbH, München, FRG.

\section{Chemicals and other materials}

Non-radioactive steroids were purchased either from Merck, Darmstadt (FRG), Makor, Jerusalem (Israel), or Steraloids, Wilton N. H. (USA), and were stored in a desiccator before use. Tris-buffer (tris(hydroxymethyl)aminomethane), acetic acid $0.96 \mathrm{~kg} / \mathrm{l}$, benzene, dichloromethane, ethanol, isooctane, and methanol were obtained from Merck. All solvents were highly purified. Human $\gamma$-globulin (Beriglobin ${ }^{\circledR}$ ) and Freund's adjuvant were obtained from Behring, Marburg (FRG), charcoal (Norit A) from Serva, Heidelberg (FRG) and dextran from Fluka, Neu Ulm (FRG).

Buffer solution was $0.05 \mathrm{~mol} / \mathrm{l}$ Tris buffer $\mathrm{pH} 8$ (adjusted with acetic acid) and human $r$ globulin $0.1 \mathrm{~g} / \mathrm{l}$. Charcoal-dextran solution consisted of $3 \mathrm{~g} / \mathrm{l}$ charcoal and $1.2 \mathrm{~g} / \mathrm{l}$ dextran suspended in Tris-buffer. Antisera were raised in female New Zealand white rabbits (mean age: 6 months, mean body weight: $1.2 \mathrm{~kg}$ ).

\section{Preparation of antigens}

Antigens were synthesized according the procedure described by Erlanger (7).

\section{Immunisation}

The first injection consisted of $3 \mathrm{mg}$ of the respective antigen dissolved in a mixture of $0.5 \mathrm{ml}$ isotonic saline and $0.5 \mathrm{mg}$ complete Freund's adjuvant. The following injections consisted of $1 \mathrm{mg}$ antigen in the same mixture and were carried out during the first three weeks at 8 day intervals, then in three weekly intervals for the subsequent booster-injections. One half of the antigen was injected intramuscularly and the other intradermally 10-15 times. Five animals were immunised for each antigen in parallel. Antisera titre was calculated as the dilution of antiserum which bound a fraction of 0.5 of the tested radioactive antigen.

\section{Specifity}

Cross reactions of the different steroids were estimated according to the method described by $A$ braham (8). Procedures were performed under assay conditions. Only biologically active $C_{19}$ and $\mathrm{C}_{21}$ steroids were tested.

\section{Affinity constant}

The standard curves of the different antisera were analysed mathematically according to the method described by Nisonoff (9) and Scatchard (10).

\section{Extraction of plasma samples}

Amounts of each steroid corresponding to 8000 counts/min dissolved in a total volume of $50 \mu \mathrm{l}$ methanol were added as internal standards to $1 \mathrm{ml}$ of plasma. Plasma was extracted with $40 \mathrm{ml}$ icecold dichloromethane in a rotating shaker after an equilibration period of $15 \mathrm{~min}$. The aqueous and the organic phase were separated and, thereafter, dichloromethane was evaporated to dryness under a gentle stream of nitrogen.

\section{Chromatography}

Descending paper chromatography was performed in closed tanks. For simultaneous separation of the spectrum of steroids by one chromatographic step the system isooctane benzene methanol 
$\mathrm{H}_{2} \mathrm{O}=60 \mathrm{ml}+140 \mathrm{ml}+120 \mathrm{ml}+80 \mathrm{ml}$ was used. Evaluation of the procedure is described in detail elsewhere (11).

\section{Assay procedures}

All incubations were prepared in $500 \mu$ l volumes. $500 \mu l$ dextrancoated charcoal suspension was added to incubations for separating bound and free radioactivity. Only those antisera of the five steroid antigens were used which showed the highest titre at the end of the immunisation procedure. Standard curves and cross reaction analyses were performed for all steroids in buffer solution with $100 \mu \mathrm{l}$ diluted antiserum, $100 \mu \mathrm{l}$ of the respective radioactive steroid, $100 \mu \mathrm{l}$ non-radioactive steroid, and $200 \mu \mathrm{l}$ as volume substitution. For standard curves of deoxycorticosterone $200 \mu \mathrm{l}$ buffer were replaced by $200 \mu$ l eluate from a pure paper strip to compensate for contingent unspecific blanks that might be introduced in radioimmunoassay tubes by the paper eluate containing the unknown steroid. Sensitivity analyses of deoxycorticosterone were performed in buffer solution. Preincubation was at $20^{\circ} \mathrm{C}$ for $30 \mathrm{~min}$ with gently shaking. Incubation was at $4{ }^{\circ} \mathrm{C}$ for 24 hours.

Radioimmunoassay of aldosterone, 18-hydroxycorticosterone, 18-hydroxydeoxycorticosterone and deoxycorticosterone (unknown samples)

After eluting the respective bands from the paper strips with $10 \mathrm{ml}$ methanol, the evaporated methanol specimens were dissolved in $1 \mathrm{ml}$ buffer for 1 hour. $300 \mu \mathrm{l}$ were taken for recovery analyses. $300 \mu \mathrm{l}$ were pipetted in duplicate into radioimmunoassay tubes, together with $100 \mu \mathrm{l} \gamma$-globulin buffer (containing 1000 counts $/ \mathrm{min}$ radioactive steroid) and $100 \mu \mathrm{l}$ diluted antiserum.

\section{Radioimmunoassay of corticosterone (unknown samples)}

The respective band from the paper strip was eluted with $10 \mathrm{ml}$ methanol. The methanol was evaporated and the residue dissolved in $2 \mathrm{ml}$ buffer for 1 hour. $500 \mu \mathrm{l}$ were taken for recovery analyses. $50 \mu \mathrm{l}$ were pipetted in duplicate into tubes, to which the following solutions were added: $100 \mu \mathrm{l} \gamma$-globulin buffer (containing 2000 counts/min radioactive steroid), $250 \mu \mathrm{l} \gamma$-globulin buffer (volume substitution), and $100 \mu l$ diluted antiserum.

\section{Quality-control of radioim munoassay}

For quality control purposes, two $1 \mathrm{ml}$ samples.of plasma from patients with bilateral adrenalectomia (" 0 -plasma") and two $1 \mathrm{ml}$ of pool-plasma ("standard-plasma") were analysed in the same way as unknown samples in each radioimmunoassay.

\section{Studies in human volunteers}

15 healthy male volunteers aged 24 to 47 (mean $34 \pm 2$ ) years were included in the study and were fully informed of the experimental nature and the potential risks of the investigational drug. Written informed consent was obtained. Subjects were investigated under ambulatory conditions and ad libitum diet between $8 \mathrm{a} . \mathrm{m}$. and $1 \mathrm{p}$.m. Studies were performed in active orthostasis. Blood pressure (random zero sphygmomanometer) and heart rate were recorded twice in the sitting position $(2 \mathrm{~min}$ rest) before the oral ingestion of $100 \mathrm{mg}$ captopril and $1 / 2,1,112$, and $3 \frac{1}{2}$ hours thereafter. Excretion of sodium and potassium was measured in the urine samples collected for $90 \mathrm{~min}$ before and for $90 \mathrm{~min}$ after captopril. Venous blood was drawn before, and $1 / 2,11 / 2$, and $31 / 2$ hours after captopril. Samples were collected in heparinized tubes and were centrifuged immediately. Plasma was stored at $20^{\circ} \mathrm{C}$. The same protocol was performed again 14 days later under prostaglandin blockade with $200 \mathrm{mg}$ indometacin (50 mg, respectively, at 1 a.m., 6 a.m., and at 9.30 a.m. together with captopril).

\section{Statistical analyses}

Values are mean \pm S.D. for methodological values and mean \pm S.E.M. for experimental results. Linear regression analyses and Student's t-test were used for statistical evaluation.

\section{Results}

\section{Evaluation of the method}

\section{Antisera}

Kinetic data of the antisera are listed in table 1. Those animals were evaluated which showed the highest titre levels of the different antigens at the end of the immunisation procedure. The standard curves of the antisera ( $n=10$ for each steroid) showed a statistically significant difference between 0 and $3 \mathrm{pg}\left(B_{0} / T \pm S\right.$.D.) for all antisera: 18-hydroxycorticosterone, aldosterone, corticosterone and deoxycorticosterone $(p<0.01)$. Thus, $3 \mathrm{pg}$ of each steroid could be distinguished from zero by the respective antisera (sensitivity). All antisera were tested against at least 12 biologically relevant steroids (specificity). Cross-reactivity of the different antisera are shown in table 2.

\section{Extraction and chromatography}

The following radioactivity recovery rates for the five steroids were obtained after extraction and chromatography $(\mathrm{n}=10)$ : 18 -hydroxycorticosterone $39 \pm 7$, aldosterone $37 \pm 7$, 18-hydroxydeoxycorticosterone $38 \pm 5$, corticosterone $40 \pm 6$, and deoxycorticosterone $50 \pm 8 \%$.

\section{Assay parameters}

\section{Precision}

Within assay variation was determined from ten replicate measurements in the same assay of samples from a plasma pool (intraassay). The following values were found (coefficient of variation in parenthesis): 18-hydroxycorticosterone $231 \pm 29(12.5 \%)$, aldosterone $146 \pm 13$ (8.9\%), 18-hydroxydeoxycorticosterone $112 \pm 11$ (9.8\%) and deoxycorticosterone $196 \pm 21 \mathrm{ng} / \mathrm{l}(10.7 \%)$; corticosterone $5.04 \pm 0.37 \mu \mathrm{g} / 1(7.3 \%)$. Between assay variation was evaluated from samples of the same plasma pool determined in five different assays (interassay): 18hydroxycorticosterone $258 \pm 38$ (14.7\%), aldosterone $137 \pm 15$ (10.9\%), 18-hydroxydeoxycorticosterone

Tab. 1. Comparison of kinetic data of the used antisera. $\mathrm{K}_{\mathrm{D}}=$ Affinity constant.

\begin{tabular}{|c|c|c|c|}
\hline \multirow{2}{*}{$\begin{array}{l}\text { Antisera } \\
\text { against }\end{array}$} & \multicolumn{2}{|c|}{$\begin{array}{l}\text { Characteristics of the antisera } \\
\text { Final } \quad K_{D}(\mathrm{~mol} / \mathrm{l})\end{array}$} & \multirow{2}{*}{$\begin{array}{l}\begin{array}{l}\text { Number of } \\
\text { booster } \\
\text { injections }\end{array} \\
4\end{array}$} \\
\hline & 1: 3500 & $2.3 \times 10^{-10}$ & \\
\hline Aldosterone & $1: 150000$ & $1.1 \times 10^{-10}$ & 6 \\
\hline $\begin{array}{l}\text { 18-Hydroxydeoxy- } \\
\text { corticosterone }\end{array}$ & 1: 70000 & $1.6 \times 10^{-10}$ & 6 \\
\hline Corticosterone & 1: 25000 & $1.6 \times 10^{-10}$ & 8 \\
\hline Deoxycorticosterone & $1: 30000$ & $1.6 \times 10^{-10}$ & 6 \\
\hline
\end{tabular}


Tab. 2. Cross-reactivity in per cent of the tested antisera with different biologically active steroids.

\begin{tabular}{lccccc}
\hline $\begin{array}{l}\text { Cross- } \\
\text { reacting }\end{array}$ & $\begin{array}{l}18 \text {-Hydroxy- } \\
\text { corticosterone }\end{array}$ & Aldosterone & $\begin{array}{l}\text { 18-Hydroxy- } \\
\text { deoxy- } \\
\text { corticosterone }\end{array}$ & $\begin{array}{l}\text { Cortico- } \\
\text { sterone }\end{array}$ & $\begin{array}{l}\text { Deoxycortico- } \\
\text { sterone }\end{array}$ \\
\hline 18-Hydroxycorticosterone & 100.0 & 0.142 & 3.300 & 0.255 & 0.370 \\
Aldosterone & 0.043 & 100.0 & 3.700 & 0.013 & 0.153 \\
18-Hydroxydeoxycorticosterone & 0.114 & 0.006 & 100.0 & 0.065 & 0.694 \\
Corticosterone & 0.048 & 0.153 & 0.021 & 100.0 & 0.024 \\
Deoxycorticosterone & 0.013 & 0.444 & 0.051 & 0.072 & 100.0 \\
Cortisone & 0.006 & 0.923 & 0.031 & 0.058 & 0.049 \\
Cortisol & 0.034 & 0.333 & 0.015 & 0.061 & 0.068 \\
Testosterone & 0.025 & 0.240 & 0.062 & 0.176 & 0.038 \\
Progesterone & 0.009 & 0.571 & 0.357 & 0.040 & 0.036 \\
17 $\beta$-Oestradiol & 0.013 & 0.007 & 0.015 & 0.035 & 0.014 \\
11-Deoxycortisol & 0.016 & - & - & 0.027 & 0.083 \\
Pregnenolone & 0.018 & - & 0.053 & 0.111 & 0.462 \\
Tetrahydroaldosterone & 0.016 & 0.800 & 0.025 & 0.017 & - \\
Tetrahydrocorticosterone & - & 0.070 & - & - & - \\
Tetrahydrodeoxycorticosterone & - & 0.034 & - & - & - \\
\hline
\end{tabular}

$128 \pm 15(11.7 \%)$ and deoxycorticosterone $201 \pm 28$ $\mathrm{ng} / 1$ (13.9\%); corticosterone $4.99 \pm 0.47 \mu \mathrm{g} / 1(9.4 \%)$.

\section{Accuracy}

To test the accuracy of the multi-steroid assay, known quantities of unlabelled steroids were added to $1 \mathrm{ml}$ of pool plasma taken from patients with Addison's diseases. Samples were examined by replicate analyses of each point $(n=10)$. Increasing amounts of steroids were added in physiological concentrations. In figure 1 measured steroid concentrations are plotted against the amounts of steroid added to the plasma.

\section{Blanks}

Assay blanks were evaluated from $1 \mathrm{ml}$ plasma of a bilaterally adrenalectomized patient and were included in all procedures of the assay $(n=10)$ : aldosterone $7 \pm 3$, 18-hydroxycorticosterone $8 \pm 5,18$-hydroxydeoxycorticosterone $6 \pm 3 \mathrm{ng} / \mathrm{l}$, and corticosterone $0.11 \pm 0.04$ $\mu \mathrm{g} / \mathrm{l}$. For deoxycorticosterone an assay blank of $42 \pm 13$ $\mathrm{ng} / \mathrm{l}$ steroid-free plasma was found.

Paper blanks were tested by replacing buffer solution with equal amounts of paper eluate in all tubes of the standard curves (fig. 2). In the paper eluate curve of corticosterone, bound radioactivity of all points was slightly higher than in the normal standard curve ("negative blank"). Bound radioactivity in the deoxy.corticosterone standard curve was higher than in the paper eluate curve which is consistent with a paper blank of about $10 \mathrm{pg}$ for all points determined.

\section{Practicability}

During five working days a skillful technician can determine the five different steroids in 25 plasma samples, which represents 125 steroid values per week. Calculation of the standard curves and the plasma samples is performed by electronic data processing (spline).

\section{Experimental protocol}

\section{Response to captopril without indometacin pretreatment}

Heart rate before captopril ingestion was $76 \pm 2 \mathrm{~min}^{-1}$ and remained constant during the investigation. Mean arterial blood pressure fell continuously from the basal value before captopril treatment $(97 \pm 3)$ to a minimum 1 hour thereafter $(87 \pm 2 \mathrm{mmHg} ; \mathrm{p}<0.02)$ and then increased again to pretreatment levels $3 \frac{1}{2}$ hours after captopril. Basal sodium (206 \pm 23$)$ and potassium (107 \pm 14 $\mu \mathrm{mol} / \mathrm{min}$ ) excretion remained unchanged after captopril. A continuous and significant decrease of aldosterone and 18-hydroxydeoxycorticosterone was found after inhibition of converting enzyme. 18-Hydroxydeoxycorticosterone and corticosterone, however, remained unchanged (fig. 3). Basal deoxycorticosterone level was $171 \pm 9 \mathrm{ng} / \mathrm{l}$.

\section{Response to captopril under indometacin pretreatment}

All values for heart rate (basal $70 \pm 2 \mathrm{~min}^{-1}$ ) were significantly $(p<0.05)$ and constantly lower than those without indometacin pretreatment. Mean basal blood pressure on indometacin $(97 \pm 3)$ was unchanged in comparison with the control. However, the decrease of blood pressure 1 hour after captopril ( $93 \pm 2 \mathrm{mmHg}$ ) was significantly smaller $(p<0.05)$ than in the experiment without indometacin pretreatment. Basal sodium $(201 \pm 28)$ and potassium $(103 \pm 13 \mu \mathrm{mol} / \mathrm{min})$ excretion rates under indometacin remained unchanged before and after captopril. 

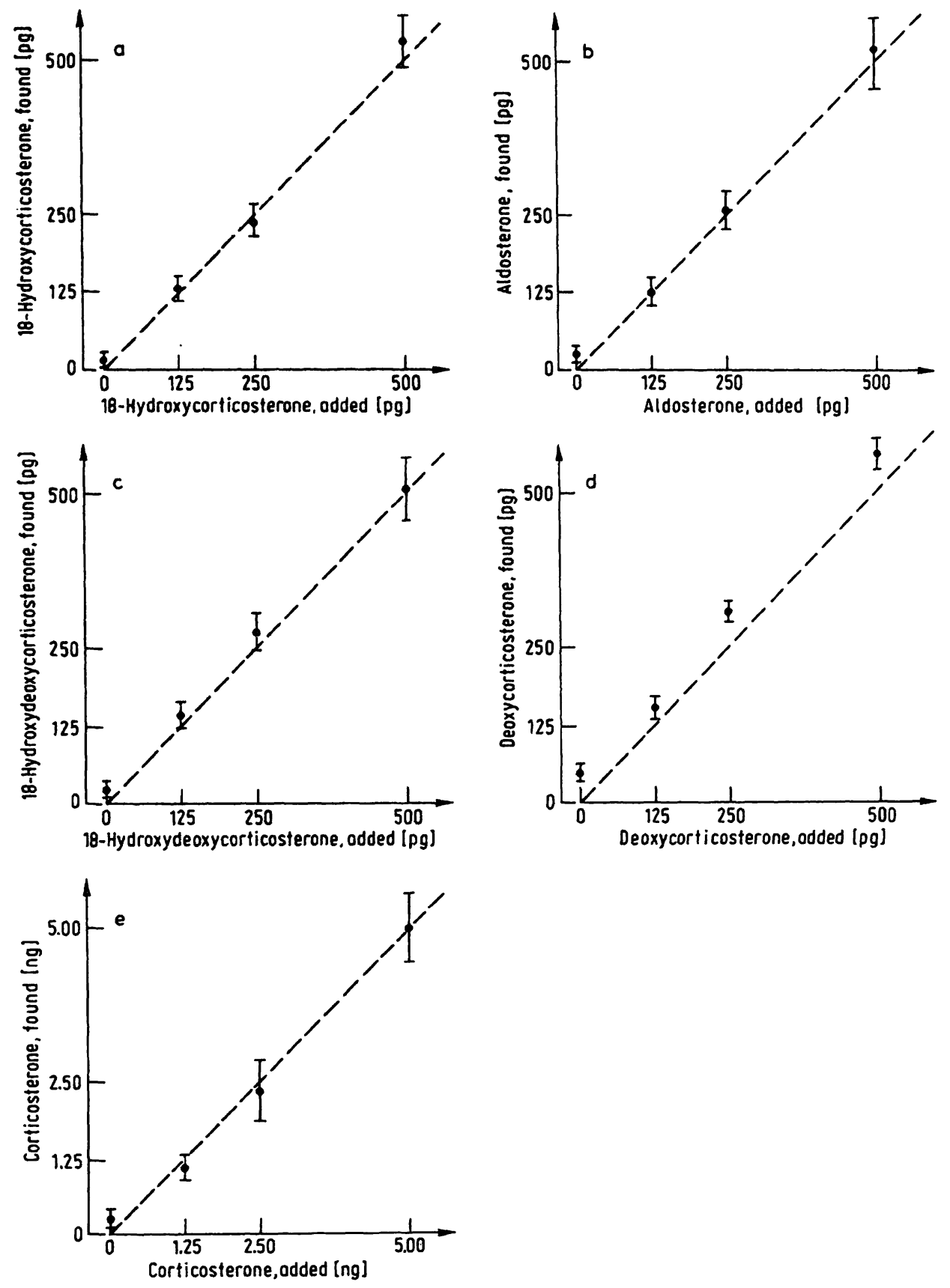

Fig. 1. Correlations between added and estimated amounts of unlabelled steroid:
a) 18-hydroxy corticosterone:
$y=5+1.02 x$
$y=12+1.01 x$
c) 18-hydroxydeoxycorticosterone:
$y=25+0.96 x$
$y=48+1.02 x$
$y=0.05+0.99 x$
$\mathrm{r}=0.98$
$r=0.98$
$r=0.98$
$r=0.99$
e) corticosterone:
$\mathrm{n}=10$.
$r \equiv$ coefficient of correlation.
$\mathbf{r}=0.98$

All control steroid levels in active orthostasis were significantly lower under prostaglandin biosynthesis inhibition. Basal deoxycorticosterone level was $119 \pm 28 \mathrm{ng} / 1$ $(p<0.05)$. Aldosterone did not change after captopril. 18-Hydroxycorticosterone remained constant $1 / 2$ hour after captopril but showed a significant decrease $1 \frac{1}{2}$ and $3^{1 / 2}$ hours after converting enzyme inhibition. However, 18-hydroxydeoxycorticosterone and corticosterone levels increased significantly $1 \frac{11 / 2}{2}$ hour after captopril (fig. 3). 

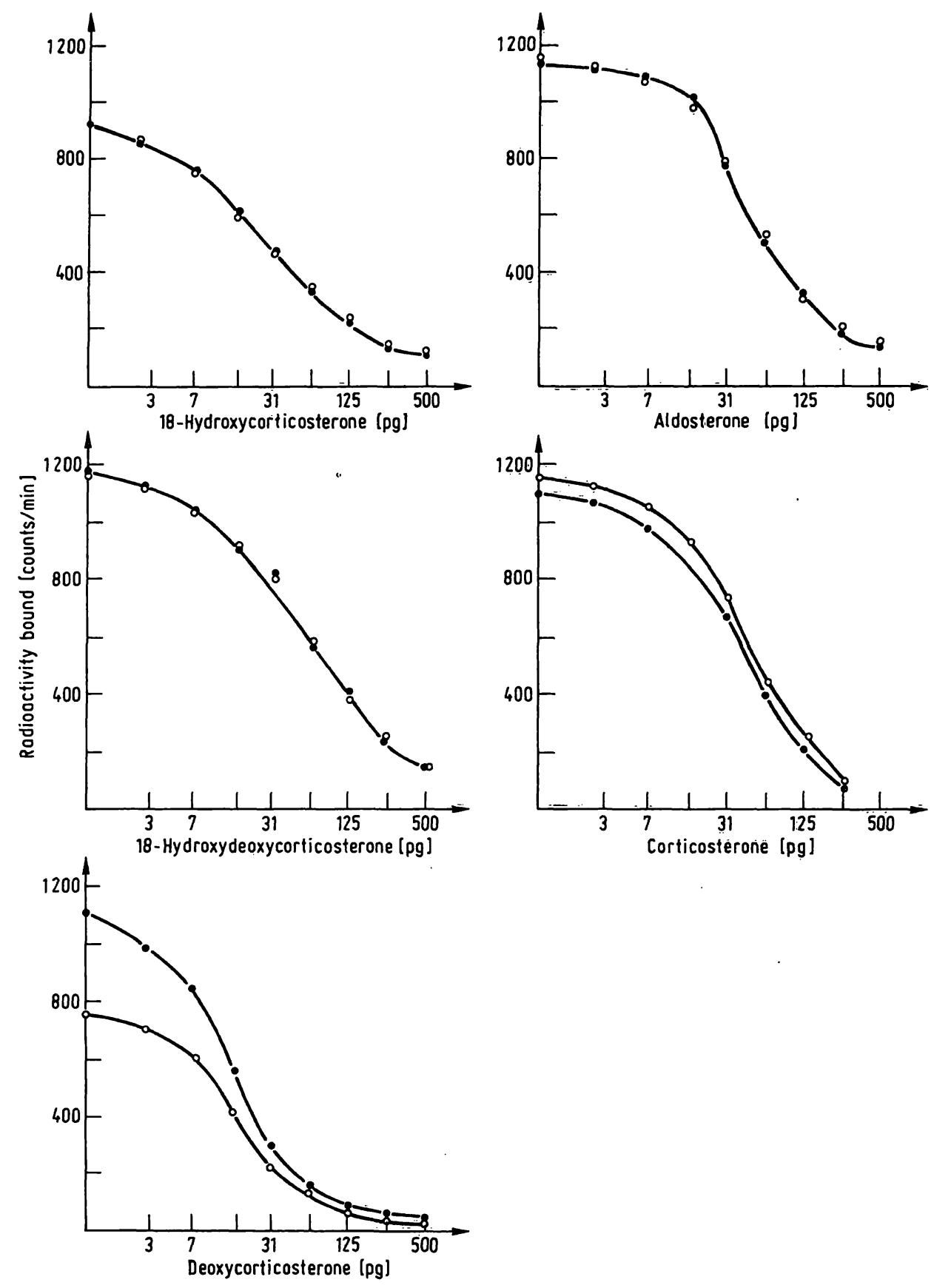

Fig. 2. Standard curves of the spectrum of steroid antisera under normal conditions (closed circles) compared with standard curves in which buffer solution was replaced by paper eluate (open circles).

\section{Discussion}

A highly specific and sensitive radioimmunoassay is described for aldosterone and its precursors 18-hydroxycorticosterone, corticosterone, deoxycorticosterone and 18-hydroxydeoxycorticosterone from $1 \mathrm{ml}$ plasma. The obvious advantage of the presented method is that very low concentrated steroids can be simultaneously estimated from a minute amount of human plasma by a simplified procedure. Specificity of the evaluated antisera was assessed by testing biologically relevant crossreacting corticosteroids. Cross-reactions were compar- able with data recently reported (12-15). No gross cross-reactivity was detected in any of the antisera. Sensitivity of the different standard curves allows the measurement of very small amounts of the respective steroid. The calculated affinity constants of the antisera are comparable to values recently reported (14, $16,17)$. Recovery rates after extraction and chromatography were in the range of $40-50 \%$ for the spectrum of mineralocorticoids. This high yield was achieved by using only one extraction- and one chromatographic step. 


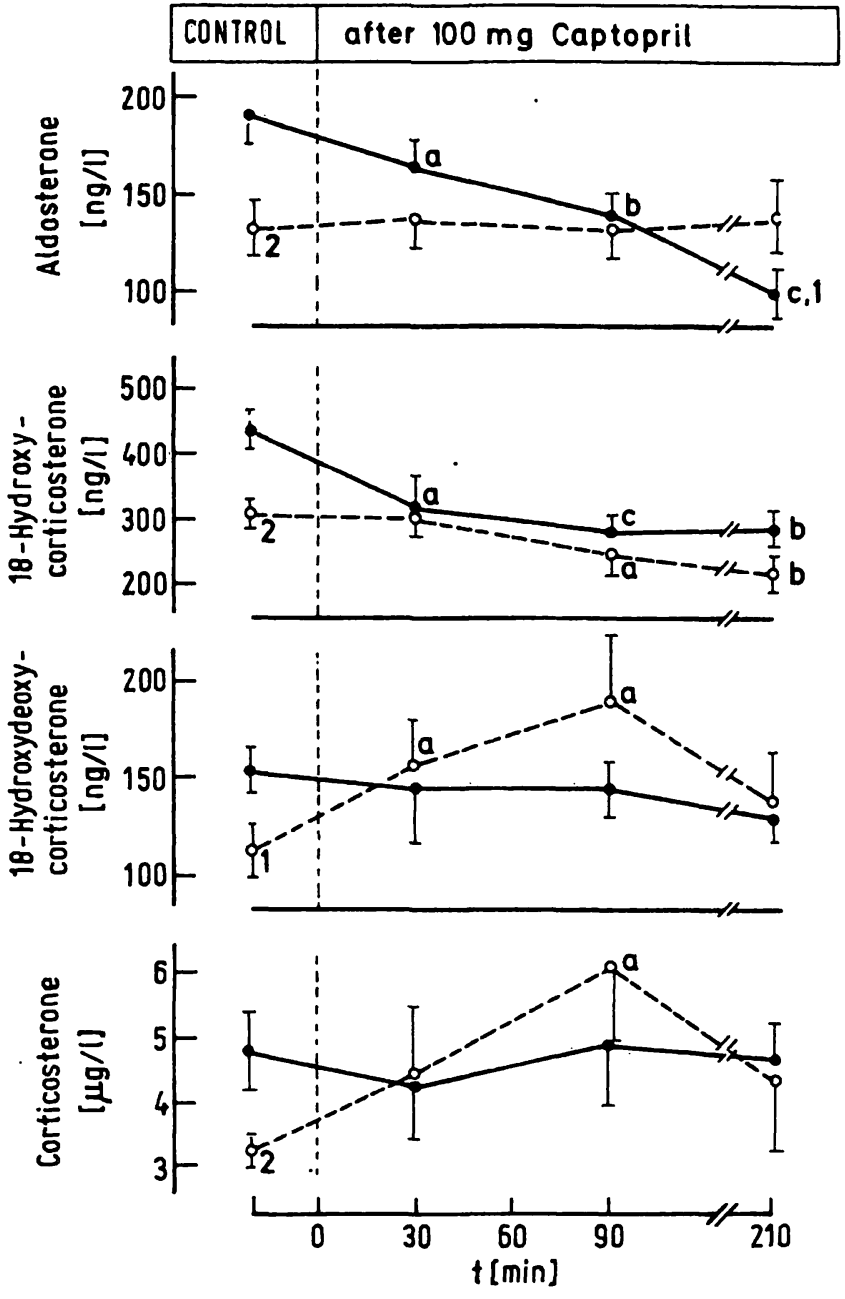

Fig. 3. Concentrations of plasma aldosterone, 18-hydroxycorticosterone, 18-hydroxydeoxycorticosterone, and corticosterone before, 30,90 , and $210 \mathrm{~min}$ after captopril. Determinations were performed both without $(\bullet-)$ and under $(0---)$ ) indometacin pretreatment. a) $\mathrm{p}<0.05$, b) $\mathrm{p}<0.01$, and c) $\mathrm{p}<0.005$ vs. respective control level.

1) $\mathrm{p}<0.05$ and 2) $\mathrm{p}<0.01$ vs. without indometacin.

Preparation and determination of 18-hydroxylated mineralocorticoids are difficult because of their known instability in acidified solutions $(18,19)$. In order to avoid formation of various compounds by reactions with the 18-hydroxyl-group, we therefore used highly purified organic solvents without any traces of acids (Uvasol ${ }^{\circledR}$ ) and all buffer solutions were alkaline $(\mathrm{pH} 8)$. So far, paper chromatography guarantees the most careful handling of 18-hydroxylated steroids compared with other chromatographic methods (e.g. thin layer or column chromatography with silica gel). In this context exposure to organic solvents is shortened by the described assay. In recently published multiple assays at least two extractions and chromatographic separations were necessary before radioimmunoassay (20-22).

For aldosterone, 18-hydroxycorticosterone, 18-hydroxydeoxycorticosterone, and corticosterone no relevant assay blanks could be detected. The blanks evaluated from plasma of a patient with bilateral adrenalectomy were found to be below the sensitivity of the respective standard curves. This was consistent with the result, that no paper blanks of those steroids could be demonstrated. The deoxycorticosterone assay blank of about $40 \mathrm{ng} / \mathrm{l}$ was mainly due to the paper blank of this steroid, which covered the complete standard curve. Several attempts failed to eliminate or reduce the paper blank of this assay. Blank-free conditions could only be established by displacing buffer solution with paper eluate for constructing the standard curve (23). By this manipulation, the assay sensitivity of deoxycorticosterone was considerably reduced.

Standard curves of our assay were evaluated with a small amount of tracer (2000 counts/min). Depending on the specific radioactivity of the different steroids, the quantity added to the antigen in the respective radioimmunoassay tube varied from a minimal $4.4 \mathrm{pg}$ (aldosterone) to a maximal $14.8 \mathrm{pg}$ (18-hydroxycorticosterone). This is of great importance with respect to the low concentrations of steroids (mean plasma concentration: 50-200 $\mathrm{ng} / \mathrm{l})$. Assays for these steroids were so constructed that tracer amounts used for recovery analyses of samples after extraction and chromatography could partly be taken for radioimmunoassay (about 1000 counts/min for $40 \%$ total recovery). Therefore only 1000 counts/ min must be added to assay tubes to fit the 2000 counts/min of the standard curves (24). The methodological procedure needs a very careful and accurate handling of all samples to provide constant recovery rates.

\section{Studies in human volunteers}

Studies were performed in normotensive volunteers under ambulatory conditions (active orthostasis) without any instructions for diet in the sodium replete state. Captopril induced a sustained fall in aldosterone (25) and 18-hydroxycorticosterone without indometacin pretreatment. Corticosterone and 18-hydroxydeoxycorticosterone remained unchanged after captopril. Inhibition of the conversion of angiotensin I to angiotensin II by captopril is the most probable reason for the fall in aldosterone and 18-hydroxycorticosterone. This may support the hypothesis that aldosterone and 18-hydroxycorticosterone are more sensitive to changes of angiotensin II levels than corticosterone and 18-hydroxydeoxycorticosterone which are mainly regulated by corticotropin $(21,26)$. The inhibition of prostaglandin biosynthesis by indometacin was accompanied by a significant decrease of all control steroid levels during active orthostasis, which may be due to the inhibition of the adrenocortical prostaglandin system. On the other hand, intrarenal prostaglandins stimulate renin release (27). Inhibition of renal prostaglandin formation reduces renin secretion, which results in diminished basal angiotensin II plasma levels under indometacin. 
This mechanism, in addition, may further decrease aldosterone and 18-hydroxycorticosterone levels. Basal plasma levels of aldosterone and 18-hydroxycorticosterone under control conditions were greatly reduced by indometacin, and no or only a smaller decrease was found after captopril without indometacin pretreatment. Under inhibition of prostaglandin biosynthesis a significant increase of corticosterone and 18-hydroxydeoxycorticosterone was found $1 \frac{1}{2}$ hour after captopril. The reason for this behaviour remained unresolved. Two possible mechanisms should be discussed:

(1) Since corticosterone and 18-hydroxydeoxycorticosterone are mainly regulated by corticotropin, an augmented corticotropin secretion could be responsible: Under indometacin, vasodilating vascular prostaglandins are diminished, thus resulting in an increased peripheral vascular resistance (28). Maintenance of control blood pressure was achieved by a compensatory reduction of heart rate. In this labile haemodynamic equilibrium the application of the blood pressure lowering drug, captopril, may be a prominent stress stimulus for the organism, which might consequently contribute to an enhanced corticotropin secretion;

\section{References}

1. Saruta, T. \& Kaplan, N. M. (1972), J. Clin. Invest. S1, 2246-2251.

2. Honn, V. K. \& Chavin, W. (1976), Biochem. Biophys. Res. Comm. 72, 1319-1326.

3. Laychock, S. G. \& Rubin, R. P. (1975), Prostaglandins 10, 529-540.

4. Campbell, W. B., Gomez-Sanchez, C. E., Adams, B. V., Schmitz, J. M. \& Itskovitz, H. D. (1979), J. Clin. Invest. 64, 1552-1557.

5. Laychock, S. G. \& Walker, L. (1979), Prostaglandins 18, 793-809.

6. Matsuoka, H., Tan, S. Y. \& Mulrow, P. J. (1980), Prostaglandins 19, 291-298.

7. Erlanger, B., Borck, F., Beiser, S. M. \& Liebermann, S. (1957), J. Biol. Chem. 228, 713-721.

8. Abraham, G. E. (1969), J. Clin. Endocrinol. 29, 866-875.

9. Nisonoff, A. \& Pressman, D. (1957), J. Immunol. 80, 417-423.

10. Scatchard, G. (1949), Ann. N. Y. Acad. Sci. 51, 660-669.

11. Witzgall, H. \& Hassan-Ali, S. (1980), J. Chromatography $198,70-75$

12. Martin, V. J., Edwards, C. R. W., Biglieri, E. G., Vinson, G. P. \& Bartter, F. C. (1975), Steroids 26, 591-604.

13. Vecsei, P., Penke, B. \& Joumaah, A. (1972), Experientia $28,622-628$.

14. Hornung, J., Gless, K. H., Abdelhamid, S., Vielhauer, W. \& Vecsei, P. (1978), Clin. Chim. Acta 87, 181-188.

15. Castro, A., Bartos, D., Jelen, B. \& Kutas, M. (1973), Steroids 22, 851-858.
(2) On the other hand, an elevated sensitivity and/or number of corticotropin receptors on zona fasciculata cells must be considered. Recently it has been shown that the inhibition of the prostaglandin system effected an increase of $\beta$-adrenoreceptors on human leukocyte membranes (29). A similar mechanism for corticotropin receptors on the level of zona fasculata cells could explain our findings.

The data of our experiments suggest that inhibition of adrenocortical prostaglandin biosynthesis by indometacin decreased all basal steroid levels, but could not prevent an augmented secretion of corticosterone and 18-hydroxydeoxycorticosterone after captopril administration.

\section{Acknowledgements}

The authors wish to thank

Dres B. Penke and J. Varga, Budapest, Hungary, for synthesizing aldosterone-, corticosterone-, and 18-hydroxydeoxy corticosterone antigens;

Dr. R. K. Liedtke (E. R. Squibb, von Heyden, Regensburg, FRG) for supplying captopril.
16. Sulon, J., Palem-Vliers, M.; Genard, P., Cittanova, N. \& Desfosses, B. (1976), Clin. Chim. Acta 72, 275-284.

17. Sancho, D. \& Haber, E. (1978), J. Clin. Endocrinol. Metab. 47, 391-399.

18. Roy, A. K., Ramirez, L. C. \& Ulick, S. (1976), J. Steroid Biochem. 7, 81-87.:

19. Aragones, A., Gros,.E. G., Lantos, C. P. \& Locascio, G. A. (1978), J. Steroid Biochem: 9, 175-180.

20. Mason, P. A. \& Fraser, R. (1975), J. Endocrinol. 64 , 277-288.

21. Schöneshöfer, M. (1977), J. Steroid Biochem. 8, 995-1009.

22. Sippell, W. G., Bidlingmaier, F., Becker, H., Brüssing, T., Dörr, H., Hahn, H., Golder, W., Hollmann, G. \& Knorr, D. (1978), J. Steroid Biochem. 9, 63-74.

23. Schöneshöfer, M., Oelkers, W. \& Harendt, H. (1975), J. Clin. Chem. Clin. Biochem. 13, 143-147.

24. Klumpp, F., Rössiler, R. \& Klaus, D. (1974), J. Clin. Chem. Clin. Biochem. 12, 128-134.

25. Johns, D. W., Baker, K. M., Ayers, C. R., Vaughan, E. D., Carey, R. M., Peach, M. J., Yancey, M. R., Ortt, E. M. \& Williams, S. C. (1980), Hypertension, 2, 567-575.

26. Melby, J. C., Dole, S. L., Grekin, R. J., Gaunt, R. \& Wilson, T. E. (1972), Recent Progr. Hormon. Res. 28, 287-351.

27. Weber, P. C., Larsson, C., Anggard, E., Hamberg, M., Corey, E. J., Nicolaou, K. C. \& Sammelsson, B. (1976), Circ. Res. $39,868-874$.

28. Wennmalm, A. (1978), Clin. Sci. Mol. Med. 54, 141-148.

29. Güllner, H.G., Kafka, M. S. \& Bartter, F. C. (1980), Clin. Sci. $59,397-400$.
Dr. med. Helmut Witzgall Mëdizininische Klinik Innenstadt Ziemssenstr. 1a D $=8000$ Mürichen 2 